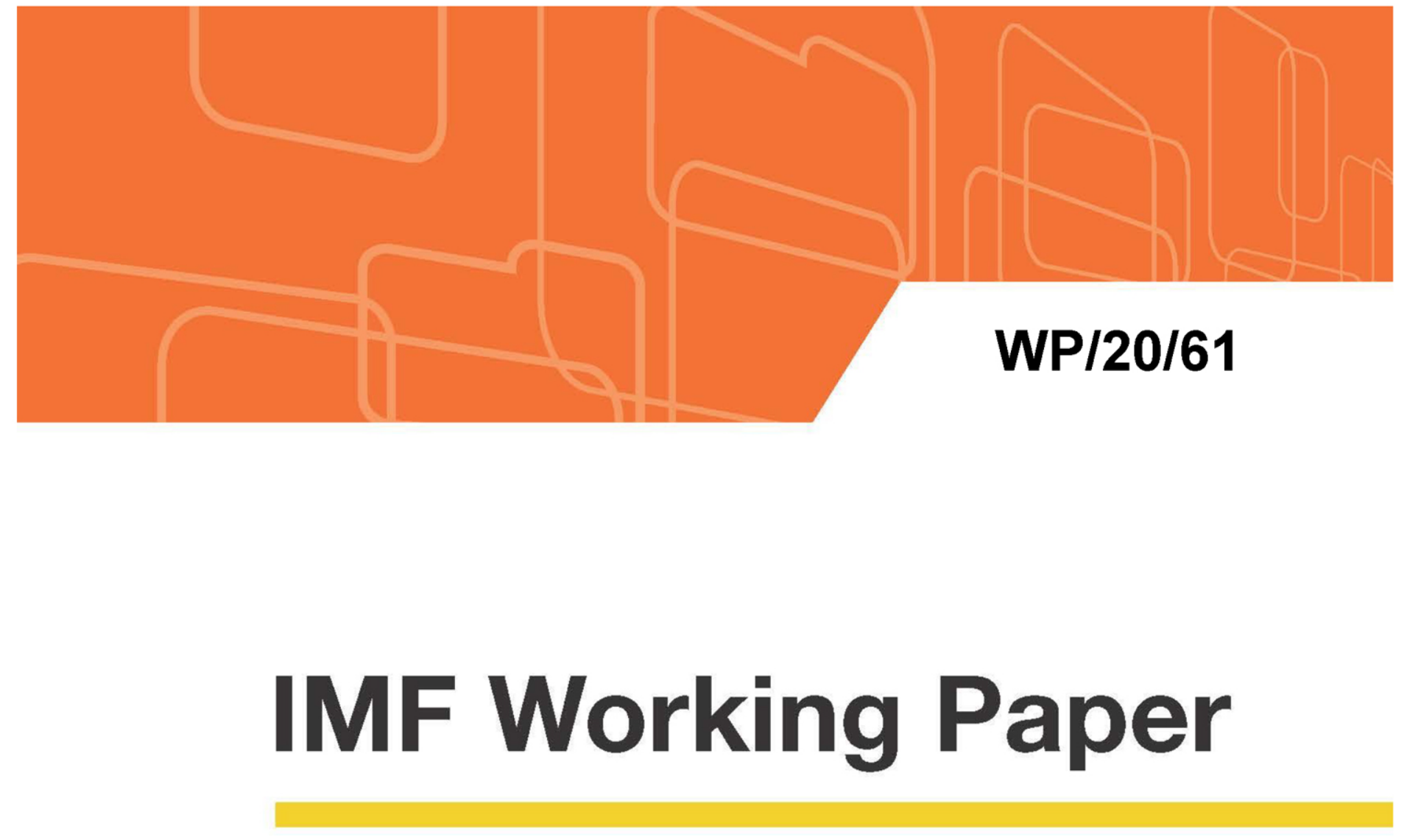

\title{
Are Capital Goods Tariffs Different?
}

by Sergii Meleshchuk and Yannick Timmer

IMF Working Papers describe research in progress by the author(s) and are published to elicit comments and to encourage debate. The views expressed in IMF Working Papers are those of the author(s) and do not necessarily represent the views of the IMF, its Executive Board, or IMF management. 


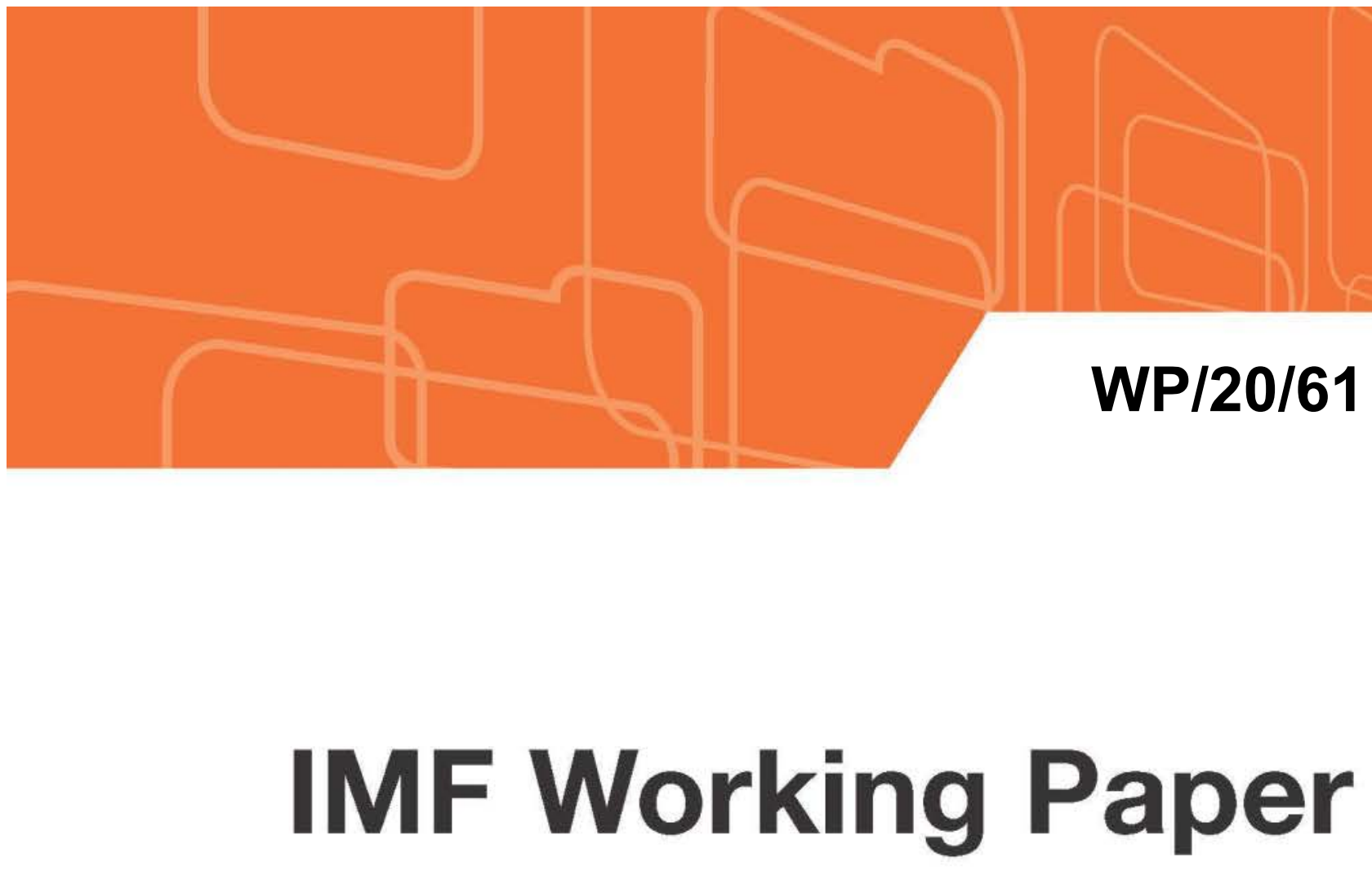

\section{Are Capital Goods Tariffs Different?}

by Sergii Meleshchuk and Yannick Timmer

IMF Working Papers describe research in progress by the author(s) and are published to elicit comments and to encourage debate. The views expressed in IMF Working Papers are those of the author(s) and do not necessarily represent the views of the IMF, its Executive Board, or IMF management. 


\title{
IMF Working Paper
}

Research Department

\section{Are Capital Goods Tariffs Different?*}

\section{Prepared by Sergii Meleshchuk and Yannick Timmer}

Authorized for distribution by Maria Soledad Martinez Peria

May 2020

\section{IMF Working Papers describe research in progress by the author(s) and are published to} elicit comments and to encourage debate. The views expressed in IMF Working Papers are those of the author(s) and do not necessarily represent the views of the IMF, its Executive Board, or IMF management.

\begin{abstract}
In this paper we demonstrate the importance of distinguishing capital goods tariffs from other tariffs. Using exposure to a quasi-natural experiment induced by a trade reform in Colombia, we find that firms that have been more exposed to a reduction in intermediate and consumption input or output tariffs do not significantly increase their investment rates. However, firms' investment rate increase strongly in response to a reduction in capital goods input tariffs. Firms do not substitute capital with labor, but instead also increase employment, especially for production workers. Reduction in other tariff rates do not increase investment and employment. Our results suggest that a reduction in the relative price of capital goods can significantly boost investment and employment and does not seem to lead to a decline in the labor share.
\end{abstract}

JEL Classification Numbers: D22, D25, E22, E24, F13, F14

Keywords: Investment, Tariffs, Capital Goods, Price of Capital, Employment, Trade reform, Colombia

Author’s E-Mail Address: $\underline{\text { SMeleshchuk@imf.org; YTimmer@imf.org }}$

\footnotetext{
* This draft: March 4, 2020. We are thankful to Emine Boz, Gita Gopinath, Andrei Levchenko, Diego Cerdeiro, Petia Topalova, and seminar and conference participants at the IMF, Banco de la Republica, Fedesarrollo, and the European Economics Association for helpful comments. The views expressed in the paper are solely those of the authors and do not necessarily represent the views of the IMF.
} 


\section{Introduction}

Trade liberalization can be an important policy tool, but which tariffs should policy makers change to stimulate investment? Both standard trade models and the empirical literature do not provide an answer to this question, as they do not distinguish capital goods from intermediate or consumption goods.

In this paper we show that this distinction is highly important. We use an event-study approach around a 2011 tariff reform in Colombia and leverage the various exposure to tariff cuts across firms in different manufacturing sectors to study whether lower tariffs stimulate or dampen firm-level investment rates. We find that, on average, the reduction in tariffs on goods which firms use as inputs has a small and insignificant effect on firm-level investment rates. This result, however, masks a significant degree of heterogeneity in responses to different types of tariffs. The reduction in tariffs on capital goods firms use as inputs has an economically strong and statistically significant effect on investment rates. There is virtually no impact on investment from a reduction in tariffs on non-capital inputs or the tariffs on goods similar to those that firms produce.

We further inspect the heterogeneous responses across firms to tariff cuts on capital inputs. We find the effect to be strongest for the firms in the third quartile of the size distribution. We show that the results are not affected by the inclusion of a set of standard control variables, are robust to different measures of the exposure to tariff reduction, and remain unchanged when we instrument the change in tariffs with the level of tariffs before the liberalization episode. Abstracting from general equilibrium effects and assuming that a firm that did not face a reduction in capital goods tariffs did not change its investment rate due to the tariff reform we can calculate the overall effects of the tariff reform. Our results suggest that the average firm increased its investment rate by 0.4 percentage points in 2011 which translates to a $7 \%$ increase in investment due to the reduction in capital goods tariffs.

These results suggest that a reduction in the price of capital goods can significantly boost investment. However, firms may also respond to a reduction in price of capital by substituting away from labor, along the lines of Karabarbounis and Neiman (2013). While the total welfare effects of trade liberalization in this case can still be positive, there can be substantial distributional asymmetries of the gains. To understand the distributional consequences of trade liberalization, we augment our analysis of investment by looking at how the reduction in tariffs affects firm-level employment. We do not find evidence in support of the hypothesis that a reduction in the price of capital goods decreases employment. In contrast, we find that firms that have been more exposed to a reduction in capital good input tariffs increase employment of production workers. We do find, however, that lower tariffs on intermediate goods can reduce firm-level employment.

The Colombian tariff reform that took place in 2011 is arguably a natural experiment that allows us to study the effects of a fall in tariffs on the performance of firms across various sectors. According to the 
Ministry of Commerce, Industry, and Tourism (MCIT), the objectives of the reform were "Reduce tariff dispersion, simplify customs administration, speed up economic growth, generate more employment and reduce poverty." ${ }^{1}$ Consequently, between 2010 and 2011, the average tariff rate on imported goods declined by close to 4 percentage points, from 12.5 percent in 2010 to 8.7 percent in 2011 (Figure 1). The reform was aimed at reducing the level and dispersion of import tariffs on a broad range of goods and was designed to boost economic activity in general, rather than in particular manufacturing sectors. The latter feature of the reform is crucial for our identification strategy which relies on the assumption that the change in sectoral tariffs was orthogonal to other sectoral shocks in 2011. Figure 2 shows that the good-specific reduction in tariffs in 2011 was highly correlated with the initial level of the tariffs before the reform. This confirms that the reform was specifically targeted to reduce the dispersion in tariffs for all goods rather than to boost investment in specific sectors.

The effect of trade liberalization on firm-level investment is not clear cut from a theoretical perspective. First, consider tariffs on goods that are close substitutes to firms' output. The fall in these output tariffs is likely to increase competition, and the effect of higher competition on firm-level investments can be ambiguous. On the one hand, higher competition can reduce firm's market share, implying a lower optimal scale of production and lower investment rates. On the other hand, a more competitive environment can stimulate firms to invest into more efficient types of capital to escape competition. ${ }^{2}$ In addition, trade liberalization that improves firm-level productivity (Amiti and Konings, 2007; Topalova and Khandelwal, 2011) may encourage firms to invest more. Finally, Gutiérrez and Philippon (2017) argue that lower competition has lead to lower investment rates in the US. To test this channel, we construct a measure of output tariffs for each of the 16 broad ISIC Rev 3.1 sectors as an average MFN tariff of HS 6-digit goods that are produced by those sectors.

Second, consider tariffs on the goods that firms use as capital or intermediate inputs in production. From this perspective, a reduction in tariffs decreases the price of capital or the price of intermediate inputs that the firm faces. A lower price on capital goods should, in principle, stimulate investment (Restuccia and Urrutia, 2001). Depending on the substitutability of capital and intermediate inputs in production, the response of investment to cuts in tariffs on intermediate inputs may vary. For example, if intermediate inputs and capital are substitutes, firms may cut their investment if the price of intermediate inputs falls. The effect will be the opposite if capital and intermediate inputs are complements in production. Using 2008 OECD input-output matrix for Colombia and a highly disaggregated microdata on import transactions, we construct variables that capture a reduction in tariffs on capital goods and other goods used as inputs in each sector. In our empirical exercise, we find that distinguishing between

\footnotetext{
${ }^{1}$ See Torres and Romero (2013) for a detailed description of the reform.

${ }^{2}$ This effect can be view as isomorphic to "escaping competition" effect in Aghion et al. (2005).
} 
capital and other goods is of utmost importance.

Our baseline results indicate that firms in sectors that are more exposed to an input tariffs cut do not significantly increase their investment. However, once we split the inputs into capital goods and other goods, we find that a decrease in capital goods input tariffs are strongly related to capital investment. A one percentage point reduction in capital goods import tariffs spurs firms' investment rates by 0.4 percentage points. These results are remarkably similar across various specifications with different sets of firm-level controls, as well as in instrumental variable (IV) regressions.

Finally, the inclusion of the change in output tariffs as an additional control yields insignificant estimates and barely affects the coefficient on capital goods input tariffs. The results are qualitatively the same both for our preferred measures of input tariffs discussed in subsection 2.2 and alternative measures that we construct in subsection 2.3

We observe substantial heterogeneity across firms in terms of their investment response to a decline in capital goods input tariffs. We find the effect of the reduction in the capital goods input tariffs to be the strongest for firms which are at the third quartile of the size distribution. These results can be generalized through the prism of models in which access to imported capital goods requires firms to incur some fixed costs. The largest firms in this environment are the ones who are willing to incur the cost even before the reduction in tariffs, and so they mostly benefit along the intensive margin, while firms who are mediumsized find it profitable to incur the cost right after the reform and thus benefit on the extensive margin of access to imported capital goods. ${ }^{3}$ Consistent with this idea, we also provide evidence that firms which are more exposed to the reduction in capital goods input tariffs are more likely to start importing.

\section{Related Literature}

This paper most closely relates to the literature on the effect of trade liberalization on firm productivity. Amiti and Konings (2007) and Topalova and Khandelwal (2011) show that lower output and input tariffs can increase productivity for Indonesia and India, respectively. Pavcnik (2002) uses Chilean data to study the impact of the reduction of output tariffs on productivity. For Brazil, Muendler (2004) shows that reduction in inward trade barriers positively affected productivity. Fernandes (2007) uses Colombian firm-level data to show that exposure to foreign competition increases productivity. ${ }^{4}$

Interestingly, the effects of trade liberalization on firm investment have not been well studied. One notable exception is Pierce and Schott (2018), who find that US firms decrease investment in response to the threat of substantial U.S. import tariff increases on Chinese goods. ${ }^{5}$ While Pierce and Schott (2018)

\footnotetext{
${ }^{3}$ These models are similar in spirit to Melitz (2003) model of exporting and Antras et al. (2017) model of importing intermediate inputs

${ }^{4}$ Using data from Argentina Bustos (2011) provides a link between a regional free trade agreement and technology upgrading.

${ }^{5}$ Gutiérrez and Philippon (2017) show that increased competition from China leads to an increase in capital stock for firms
} 
focus mainly on the competition aspect of trade liberalization, our analysis also focuses on the reduction of the cost of importing, in particular capital goods.

Therefore this paper also contributes to the literature on the relative price of capital. Economists have long hypothesized that the relative price of capital goods is one of the main determinants of investment rates and therefore economic development (De Long and Summers, 1991, 1993; Hsieh and Klenow, 2007; Lian et al., 2019).

Since capital goods production is concentrated only in a few countries, many emerging markets and developing economies are reliant on importing capital from abroad which can be associated with major distortions (Eaton and Kortum, 2001). ${ }^{6}$ Jones (1994) demonstrates a strong negative link between economic growth and the relative price of capital goods in a cross-country growth regression. He argues that reduction in tariffs results in an increase in investment and an increase in capital accumulation. However, disentangling the effect of the reduction in the relative price of capital from other factors in a cross-country growth regression is difficult. By using firm-level data and arguably exogenous exposure to reduction in capital goods tariffs, we can interpret our results as the effect of a reduction in the price of capital good on investment more causally.

The rest of the paper is structured as follows. Section 2 describes the data we use in the analysis. Sections 3 and 4 report the main results on the reaction of investment rate and employment in response to tariff cuts. Section 5 concludes.

\section{Data}

\subsection{Firm-level data}

Firm-level data comes from the 2008-2015 waves of the Colombian Annual Survey of Manufacturers (Encuesta Annual Manufacturera or EAM). The survey is conducted annually among virtually all firms in the manufacturing industry with at least 10 employees. $^{7}$ The survey has information on firm-level expenditures on different types of capital, sales, employment, fixed assets, as well as the 4-digit ISIC industry code. We construct investment as a sum of expenditures on new and used machinery and office equipment ${ }^{8}$ and calculate investment rates as a ratio of investment to fixed assets. Our main variable of interest is the change in the investment rate between 2011 and 2010 and we trim the firm-level variable at the 1st and 99th percentiles within each sector.

Table 1 show the summary statistics. The sample consists of 9,110 firms. Investment refers to in-

with high market to book values.

${ }^{6}$ Estevadeordal and Taylor (2013) demonstrate a positive link between trade liberalization and growth in a cross-country setting.

${ }^{7}$ See, for example, Kugler and Verhoogen (2011), who use a confidential version of the same survey

${ }^{8}$ We ignored investment into structures, buildings, and land. 
vestment in machinery and equipment divided by total fixed assets. $\Delta$ Investment is the change in Investment between 2011 and 2010. The average change in the investment rate was -0.3 percentage points with a standard deviation of $12.12 .{ }^{9}$ The distribution in the change in the investment rate is relatively symmetric. A firm at the 10th percentile of the distribution reduced its investment rate by 10.4 percentage points. The firm at the 90th percentile of the distribution increased its investment rate by 9.57 percentage points. The average investment rate in 2010 was 5.75 percentage point in 2010 and 5.43 percentage points in 2011. More than 25 percent of the firms do not invest in a given year but firms at the 90th percentile of the distribution have investment rates of 17.24 and 16.09 investment rates in 2010 and 2011, respectively. The distribution of the number of employees is positively skewed. The median firm has only 25 employees while the mean across firms is 74 with a standard deviation of 145 . The $\log$ of sales and fixed assets in pesos is relatively symmetrically distributed with a mean of 14.47 and 13.42, respectively. In 2010, $22 \%$ of firms were importers. This ratio dropped to $21 \%$ in 2011 but still $4 \%$ of the firms became importers in 2011.

\subsection{Tariff Measures}

The data on tariffs come from Felbermayr et al. (2018). We use the Harmonized Tariff (HS) 6-digit level (most-favored-nation) MFN tariffs for Colombia and aggregate them to construct several measures of exposure to the reduction in input tariffs at the sectoral level. ${ }^{10}$ First, we calculate output tariffs $T_{s}^{O}$ for each manufacturing sector $s$, as follows:

$$
T_{s, t}^{O}=\frac{1}{N_{s}} \sum_{h s \in S} T_{h s, t}
$$

where $h s$ indexes a particular $h s$ good, $T_{h s, t}$ is the MFN tariff rate for that good in year $t, S$ is the set of $h s$ goods that are produced by sector $s$, and $N_{s}$ is the total number of $h s$ goods that are produced by sector $s^{11}$. In other words, output tariff for a given sector is a simple average of tariffs for HS 6-digit goods that are produced in that sector. Similarly, for each sector $s$, we compute average tariffs for capital goods, $T_{s, t}^{O, C}$, and other goods, $T_{s, t}^{O,\urcorner C}$ :

$$
\begin{aligned}
T_{s, t}^{O, C} & =\frac{1}{N_{s}^{C}} \sum_{h s \in S^{C}} T_{h s, t}, \\
T_{s, t}^{O,\urcorner C} & =\frac{1}{N_{s}^{\urcorner C}} \sum_{h s \in S^{\prime C}} T_{h s, t},
\end{aligned}
$$

\footnotetext{
${ }^{9}$ The decline in investment rate reflects a more general long-term trend of decline in Colombian manufacturing.

${ }^{10}$ We define 33 sectors analogously to the way they are defined in the 2008 OECD input-output Table for Colombia.

${ }^{11} N_{S}=|S|$
} 
where $\left.S^{C}(S\urcorner^{C}\right)$ is the set of HS 6-digit capital goods (all other goods) according to the Broad Economic Categories (BEC) classification that are produced in sector $s$ and $N_{s}^{C}=\left|S^{C}\right|, N_{s}^{C}=\left|S^{C}\right|$.

To construct input tariffs, we closely follow Amiti and Konings (2007) and construct input tariffs for all goods, capital goods, and other goods $\left(T_{s, t}^{I}, T_{s, t}^{I, C}, T_{s, t}^{I,\urcorner C}\right.$ respectively) in the following manner:

$$
\begin{aligned}
T_{s, t}^{I} & =\sum_{s^{\prime}} w_{s, s^{\prime}} T_{s, t}^{O} \\
T_{s, t}^{I, C} & =\sum_{s^{\prime}} w_{s, s^{\prime}} T_{s, t}^{O, C} \\
T_{s, t}^{I, \neg C} & =\sum_{s^{\prime}} w_{s, s^{\prime}} T_{s, t}^{O,\urcorner C},
\end{aligned}
$$

where $w_{s, s^{\prime}}$ is the share of expenditures in sector $s$ on inputs from sector $s^{\prime}$ in total expenditures on intermediate inputs in sector $s^{\prime}$ taken from the 2008 input-output table for Colombia. ${ }^{12}$ In other words, our measures of sectoral input tariffs are weighted averages of output tariffs where the weights are expenditure shares on inputs from different sectors taken from aggregate input-output table. The input tariff variables capture the effect of access to cheaper inputs. Unlike earlier studies, we allow for a differential investment response to cuts in the tariffs of capital goods versus other inputs.

Figure 3 plots the tariff rate for the most and least exposed sector. The most exposed sector (in red) faced a tariff rate of $12 \%$ on their inputs between 2008 and 2010, in 2011 the rate dropped to 8\%. For the least exposed sector there was almost no change on their input tariff rate in 2011.

Table 2 shows summary statistics on the sector exposure to the tariff reform. The average sector faced a reduction in 3.14 percentage points. The average reduction in capital goods tariffs was 1.03 percentage points with a standard deviation of 1.23. The sector at the 10th percentile of the capital goods tariff change faced a reduction in capital goods tariffs of 2.92 percentage points. The sector that was least exposed only saw their capital goods tariffs reduced by 0.04 percentage points. The average reduction in tariffs on other inputs was 3.1 percentage points and the average reduction in output tariffs was 4.59 percentage points.

\subsection{Alternative Input Tariff Measures}

As a robustness check, we recompute average tariffs using the very detailed data on Colombian import transactions provided by the Colombian statistical authority (DANE). This dataset covers the universe of import transactions at the importer-HS10 good-origin-month level. Each importer can be matched to one of the particular ISIC 4-digit. For each year and each of the 1314 -digit manufacturing sectors $\widetilde{s}$ we

\footnotetext{
${ }^{12}$ We use shares of expenditures on intermediate inputs rather than capital originating in different sectors since, to our knowledge, sectoral capital expenditure shares are unavailable for Colombia. As a robustness check, we use alternative measures of exposure to tariff shock using trade-level microdata
} 
observe in the manufacturing survey, we calculate import expenditure shares on each of the HS 6-digit goods (in total import expenditures of that sector), denote them by $s h_{h s, t}^{\widetilde{s}}$, and then calculate measures of input tariffs in the following way:

$$
\begin{gathered}
\widetilde{T}_{\widetilde{s}, t}^{I}=\sum_{h s \in \Omega} s h_{h s, t}^{\widetilde{s}} T_{h s, t}, \\
\widetilde{T}_{\widetilde{s}, t}^{I, C}=\sum_{h s \in \Omega^{C}} s h_{h s, t}^{\widetilde{s}} T_{h s, t}, \\
\widetilde{T}_{\widetilde{s}, t}^{I, \neg C}=\sum_{h s \in \Omega^{\prime} C} s h_{h s, t}^{\widetilde{s}} T_{h s, t},
\end{gathered}
$$

where $\Omega, \Omega^{C}, \Omega^{C}$ is the universe of all HS 6-digit goods, 6-digit capital goods, and all other goods respectively.

Table 3 shows summary statistics for the alternative measure of tariffs.

\section{Trade liberalization and Investment Rates}

\subsection{Baseline}

The empirical approach relates the change in the firm-level investment rate before and after the tariff reform in 2011 to change in the input and output tariff rate in percentage points. In particular, we estimate the following equation:

$$
\Delta \text { Investment }_{i}=\alpha+\beta_{1} \Delta T_{s(i)}^{I}+\mathbf{X} \gamma_{1}+\epsilon_{i}
$$

where Investment $t_{i}$ is defined as investment over total fixed assets for a given firm $i$ in a sector $s(i)$, and $\mathbf{X}$ is a vector of controls including lagged logs of fixed assets and sales.

Next, we estimate the equation above again but split the change in input tariffs into the change in capital goods input tariffs and other input tariffs defined in sections subsection 2.2 and subsection 2.3. First we re-estimate the equation by replacing input tariffs with capital goods input tariffs and then we successively add other input tariffs and output tariffs. Finally we estimate the following equation:

$$
\Delta \text { Investment }_{i}=\alpha+\beta_{1} \Delta T_{s(i), t}^{I, C}+\beta_{2} \Delta T_{s(i), t}^{I, \neg C}+\beta_{3} \Delta T_{s(i), t}^{O}+\mathbf{X} \gamma_{1}+\epsilon_{i}
$$

for $t=2011$

Table 4 reports our baseline specification. Column (1) shows the effect of the exposure to overall input on the change in the investment rate. A one percentage point stronger exposure to the reduction in 
overall tariffs is associated with a 0.12 percentage points increase in the investment rate, but the coefficient is not statistically significant at conventional levels.

Column (2) only includes the exposure to capital goods input tariffs as a regressor. The regression shows that a one percentage point stronger exposure to capital good input tariff reduction is associated with a 0.377 percentage points stronger increase in the investment rate. For the average firm, for which the investment rate in 2010 was 5.75 percent (Table 1), a one percentage point stronger reduction in capital good input tariffs would increase its investment rate to 6.127 percent, a 6.6 percent increase.

The sector with the largest exposure to the change in capital goods tariffs in 2011 faced a reduction on their capital goods tariffs by 3.03 percentage points, while the least affected sector faced almost no reduction in their capital good input tariffs (a 0.03 percentage point decline). Based on our regression results, firms in the sector with the highest exposure therefore increased their investment by around 1.14 percentage point in 2011 due to their higher exposure to the reform. For the average firm that would be reflected in an increase in their investment rate from 5.75 to 6.89 , an almost $20 \%$ increase.

Column (3) adds the change in other input tariffs as an independent variable. We find the effect of the change in other input tariffs on investment to be negative but not statistically significant. The effect of the reduction in other input tariff on investment is not obvious from a theoretical perspective. If capital goods and other inputs are complements, a reduction in tariffs on other goods can increase investment. However, if both types of goods are substitutes a reduction in other input tariffs would lead to a decrease in investment. The negative effect of change in tariff on investment is consistent with recent papers that suggest that factors of production are substitutes, at least in the short-run (Atalay, 2017; Baqaee and Farhi, 2017; Bøler et al., 2015; Peter and Ruane, 2017). However, the economically small statistically insignificant effect suggest that complementarities are not large enough to boost investment dramatically.

The effect of a reduction of output tariffs on investment is also ambiguous. While a reduction in output tariffs can increase productivity by inducing competition (Amiti and Konings, 2007; Topalova and Khandelwal, 2011), foreign competition can induce firms to shrink and crowd out investment of domestic firms (Autor et al., 2013; Gutiérrez and Philippon, 2017). Column (4) shows that a decline in output tariffs indeed decreases the investment rate of domestic firms, consistent with the crowding out effect, but the effect is not statistically significant and is economically tiny.

Across columns (2)-(4) the coefficient on the change in capital good input tariffs remains remarkably stable and ranges only from -0.377 to -0.370 . The stability of the coefficient suggests that the change in the capital good import uncorrelated with both observed and unobserved variables that could bias our regression results.

To further confirm that our results are not driven by other omitted variables, we implement an in- 
strumental variable approach. As discussed before, the main idea of the trade reform was to harmonize tariff rates. Therefore, the magnitude of the tariff reduction was determined by the level of the tariff rate in 2010 Figure 2. As this level was determined many years before the trade liberalization it should not affect investment in 2011 through other factors, so we can instrument the change in the tariff rate with its level in 2010.

Table 5 displays the results of an OLS regression of the investment rate on the level of the capital goods tariff rate, the baseline OLS regression with the change in the capital goods tariff rate, and the instrumental variable regression where we instrument the reduction in the tariff rate with the level of the tariff rate in 2010. The level in the tariff rate in 2010 strongly affects the change in the investment rate between 2011 and 2010. A one percentage point larger tariff rate in 2010 raised the investment rate by 0.19 percentage points in 2011. In the instrumental variable regression, where we instrument the change in the tariff reduction with the level in 2010, the IV coefficient is very similar and not statistically different to the baseline coefficient in column (2). The F-stat of the first-stage regression is 24.54 and therefore exceeds the Stock and Yogo weak instrument test. As the OLS and the instrumental variable regression coefficients are statistically not different, we proceed with the OLS regression as it is more efficient.

\subsection{Dynamic Effects}

Figure 4 displays the coefficient of the change capital good input coefficient $\left(\beta_{1}\right)$ and the $95 \%$ and $99 \%$ confidence intervals from the following cross-sectional regressions:

$$
\text { Investment }_{i, t}-\text { Investment }_{i, 2010}=\alpha+\beta_{1} \Delta T_{s(i), 2011}^{I, C}+\beta_{2} \Delta T_{s(i), 2011}^{I, \neg C}+\beta_{3} \Delta T_{s(i), 2011}^{O}+\mathbf{X} \gamma_{1}+\epsilon_{i}
$$

where $t$ takes 2008, 2009, 2011, 2012, 2013, 2014, 2015 and 2016. $\Delta T_{s(i), 2011}^{I, C}, \Delta T_{s(i), 2011}^{I, \neg C}$ and $\Delta T_{s(i), 2011}^{O}$ are the changes in the tariffs between 2011 and 2010. The change in the investment rate between 2008 and 2010 as well as 2009 and 2010 are not significantly associated with the exposure to the capital goods input tariffs. This result can serve as a placebo test. One concern of the estimated regression could be that the exposure to the capital good tariff reduction is correlated with factors that affect the change in the investment rate between 2011 and 2010. The result that changes in firms' investment rates before the reform are not significantly correlated with exposure to the capital goods reduction provides reassurance that firms do not postpone their investment until they know the reform comes in. If that was the case, we would overestimate the causal effect of a reduction in tariffs on investment. Since we do not see that firms that have been more exposed to the tariff reform invest less in 2010 than in 2009 or 2008, this 
suggest that firms do not postpone their investment in 2010 to benefit from the the effects of the reform in 2011.

The estimated coefficient from Equation 12 also sheds light on how persistent the effect of the reduction in capital goods tariffs on investment is. As shown in Table 4 , the coefficient equals -0.37 for the change in the investment rate between 2011 and 2010. The coefficient remains negative for 2012 and 2013, but is not statistically significant in 2013 anymore. After 2013 the effect of the reduction in capital good input tariffs on the change in the investment rate relative to 2010 fluctuates around 0.

The results suggest that firms that have been more exposed to the decline in capital goods tariffs increased their capital stock more than other firms, leading to capital deepening and an increase in labor productivity.

\subsection{Heterogeneity across Firms}

The results in the previous section suggest that firms that have been more exposed to the reduction in capital goods input tariffs have significantly increased their investment rates relative to other firms. In this subsection we shed light on the heterogeneity across firms in terms of their investment response given their exposure to the capital good tariff cut. Production of capital goods is highly concentrated in a few countries. Many countries, especially in Emerging Markets, are reliant on import capital goods from abroad. Importing goods from abroad can be costly. Larger firms are more likely to self-select into importing markets because it is less burdensome for them to incur the fixed costs Bernard et al. (2018). A reduction in tariffs can decrease the fixed costs of importing and incentivize firms to start importing (Halpern et al., 2015; Goldberg et al., 2010).

Therefore, we estimate the differential effects of the tariff reduction for firms of different size. We regress the change in the investment rate on the change in the capital goods tariffs, three dummies for the size of the firm and the interaction between the dummies and the change in the capital goods tariffs. We split firms into 4 quartiles and estimate the coefficient on the interaction with four quartile $\rrbracket_{q}, q \in=$ $\{1,2,3,4\}$, where $\mathbb{\square}_{1}$ and $\mathbb{\square}_{4}$ denote the quartiles with the smallest and the largest firms respectively.

We estimate the following regression equation:

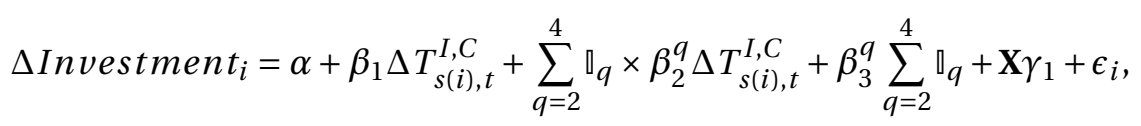

for $t=2011$

$\beta_{1}$ estimates the effect of the change of capital goods tariffs for the smallest quartile of firms within each sector. $\beta_{2}^{2}, \beta_{2}^{3}$, and $\beta_{2}^{4}$ reflect the additional impact on the change on investment for mediumsmall, medium-large, and large firms, respectively. Columns (1) and (3) of Table 6 show the results for 
Equation 13. The effect of a change in capital good input tariffs on the change in investment is negative for the small firms in terms of both sales and employment, but only statistically significant for small firms if sales are used as an indicator of size.

Firms which are in the second quartile of the employee distribution benefit more from the tariff reduction, but the effect is not statistically significant. Medium-large firms benefit most from the reduction in capital goods input tariffs. The largest firms also benefit more than small firms but the additional effect is smaller than for medium-large firms. For a firm at the third quartile of the employment distribution that is exposed to a 1 percentage point decline in capital goods input tariffs, investment increases by 0.66 percentage point more. This compares to a 0.02 percentage point increase in investment for a firm which is exposed to same reduction in input tariffs but is at the first quartile of the employment distribution.

The results are similar when sales are used to assign firms into size bins. While the second quartile of firms benefit less than the first quartile, the effect is again the strongest for firms which are at the third quartile of the sales distribution. A firm that is at the first quartile of the sales distribution increases investment by 0.367 percentage point more in response to a 1 percentage point decline in capital goods tariffs. In contrast, a medium-large firm which was exposed to the same reduction in capital goods tariffs increased investment by 0.781 percentage point. The firms at the 4 th quartile of the sales distribution does not seem to benefit more from the tariff reduction than the smallest firms.

Columns (2) and (4) re-estimate Equation 13 with sector fixed effects. By including fixed effects in the regression, we absorb all observed and unobserved heterogeneity on the sector level that could drive the change in investment rate between 2011 and 2010. For instance, if investment opportunities in a sector improved in 2010 and this sector was more exposed to the reduction in capital good input tariffs, we could overestimate the effect of the reduction in tariffs on the change in investment. By including sector fixed effects all confounding factors that are correlated with sectoral reduction in tariffs and could affect investment are controlled for. However, in this specification the sector-level exposure to the reform is collinear with the fixed effects so that we cannot estimate the overall effect of the reduction in tariffs on the change in investment. Columns (2) and (4) show that the results on the interaction terms are robust to the inclusion of the sector fixed effects. It is still the case that firms which are at the third quartile of the size distribution benefit more from the tariff reduction than small firms.

In addition, the coefficients of the interaction terms are remarkably stable and virtually do not change once fixed effects are included. Confounding factors which are correlated with the reduction in the tariffs therefore do not seem to play a large role affecting the differential impact on investment depending on size. This suggests that confounding factors which are correlated with the overall effect of the change in tariffs and affect the change in investment are likely to be minor.

In sum, we find that firms which are at the third quartile of the size distribution, i.e. medium-large 
firms, benefit most from the reduction in capital good input tariffs. This result suggest that the reduction in the fixed costs of importing makes the benefits of importing exceed the fixed costs.

\subsection{Import Entry}

In this subsection we test whether firms which have been more exposed to the reduction in capital goods input tariffs are more likely to start importing.

To shed light on the extensive margin of firm importing we estimate a probit regression. We regress the dummy Import Entry on the changes in tariffs. The dummy Import Entry takes the value one if the firm is not importing in 2010 but starts importing in 2011, and zero otherwise. Column (1) of Table 7 shows that a reduction in overall input tariffs increases the probability to start importing in 2011, but the coefficient is not statistically significant. When we split the general tariff change into the change in capital goods tariffs and other input tariffs, we find that firms which are exposed to a stronger reduction in capital goods tariffs are more likely to start importing. We do not find this effect for the change in tariffs for other goods. Interestingly, we also find that firms which are more exposed to a reduction in output tariffs are more likely to become importers. In column (4), the average marginal effect of a one percentage point reduction in capital goods input tariffs on the probability of a positive outcome is 0.005 .

\subsection{Robustness}

In this subsection we conduct two types of robustness tests. First, we add additional firm-level controls to our baseline specification. Second, we use an alternative measure of tariffs.

In Table 8 we successively add controls. In column (1) we confirm that our results hold when no controls are included. Column (2) adds only the lagged log of fixed assets, column (3) adds lagged log of sales and lagged log of total factor productivity. Finally, column (4) adds the change in the log of fixed assets and sales between 2011 and 2010 as additional controls, following Kalemli-Ozcan et al. (2018). Since many of our firms are private, we do not have information on Tobin's Q. In addition, the firm-level data we are using does not provide information on the leverage of the firm. Our base result is confirmed in all of the specification and the coefficient only varies from -0.372 to -0.376 . Since adding additional firm controls only affects the coefficient marginally, it is unlikely that other controls, such as Tobin's or Leverage, would affect our baseline result significantly. In addition, since our main variable of interest seems to be uncorrelated with the observed firm-level characteristics, it is likely that the change in capital good input tariffs is also uncorrelated with unobserved characteristics that could bias our result.

In Table 11 we use an alternative measure of input tariffs. We obtain data from the Colombian statistical authority (DANE) to construct input tariffs based on previous import volumes. See subsection 2.3 for a detailed description of the construction of the alternative tariff measure. We can confirm our base- 
line result. Firms which are exposed to a stronger decline in overall input tariffs, non-capital goods input tariffs and output tariffs do not significantly change their investment rate more than other firms. However, a larger exposure to capital goods input tariff cuts has a statistically and economically strong effect on the change in the investment rate.

\section{Trade Liberalization and Employment}

In this section we analyze the employment effects of trade liberalization. The effects are not clear-cut from a theoretical perspective. From the perspective of the Heckscher-Ohlin model , the effect of a tariff reduction on the returns on labor and capital will depend on which factor is used more intensively in sectors that face steeper tariff declines. Using a trade reform in Colombia in the 1980s and 1990s, Attanasio et al. (2004) find results which are inconsistent with the prediction from the Heckscher-Ohlin model. They show that a decline in output tariffs are not associated with a reallocation of labor but associated with declines in industry wage premiums. Although employment remained stable across sectors in response to the trade reform, one could conclude that trade liberalization is associated with a decrease in the labor share since the the wage premium falls for more exposed sectors.

However, output tariffs are not the only factor affected by the trade reform. In addition to tougher competition from abroad, induced by lower output tariffs, firms may also be able to use the same inputs from abroad at lower prices due to lower input tariffs. The fall in input tariffs may affect the withinfirm substitution between labor and capital and the sign of the effect will depend on whether labor and capital or intermediate inputs are substitutes or complements in the production.

The substitutability between labor and other inputs in production has been studied intensively in the literature. For instance, Karabarbounis and Neiman (2013) show that labor and capital are substitutes. They conclude that the decline in the price of capital has led to a substitution away from labor to capital and therefore a decline in the labor share. In contrast, Chirinko (2008) surveys the literature on the elasticity of substitution and finds that most estimates are below one, but usually smaller in the shortrun than in the long-run. Grossman et al. (2017) and Raval (2014) are more recent studies that also find an elasticity of below unity for the US. Oberfield and Raval (2014) show that the substitution between labor and capital of 0.84 for the average manufacturing sector in Colombia.

Chan (2017) and Hummels et al. (2014) study the substitutability between labor and intermediate inputs. They show that that intermediate inputs and labor are substitutes, as lower intermediate good prices induce firms to reduce in-house production of intermediate inputs. On the other hand, intermediate inputs and labor may be complements if firms need workers to process intermediate goods. Since there is substantial disagreement on the overall effects of trade liberalization and the decline in factor 
prices on employment we test firms' employment responses to a decline (i) output tariffs (ii) capital good input tariffs and (iii) non-capital good input tariffs. In addition, we shed light on the persistence of these effects and whether they are more pronounced for manual or administrative workers.

We employ the same estimation strategy as in our baseline. We test whether firms which are more exposed to the reduction in different types of tariffs have different responses in terms of the number of employees. Column (1) of Table 9 shows that a larger exposure to the decline in input tariffs is associated with a reduction in workers between 2010 and 2011 . However, as for the response in the investment rate, this result masks significant heterogeneity depending on the types of goods. A reduction in non-capital good input tariffs leads to a decline in the number of workers. This result is consistent with models in which labor and intermediate inputs are substitutes (Chan, 2017; Hummels et al., 2014) and supports the hypothesis that firms may stop producing intermediate inputs in-house as intermediate inputs become cheaper to import from abroad.

In contrast, a reduction in capital goods tariffs is associated with an increase in the number of employees. This result is in stark contrast with Karabarbounis and Neiman (2013) who argue that the decline in the price of capital is associated with a decline in the labor share as labor and capital are substitutes. Our results are consistent with models in which the elasticity between labor and capital is lower than unity, i.e. labor and capital are complements. One possible explanation for this result is that manual workers are necessary in order to use the newly purchased machines. If this hypothesis is correct, we would expect to find a stronger coefficient on manual workers than on administrative workers. Table 10 indeed shows that this is the case. The coefficient on capital goods tariffs is around $50 \%$ higher than for administrative workers, for which it is not statistically significant.

Next, we examine how persistent the effect of capital goods prices on employment is. If labor and capital are complements in the short-run but substitutes in the long-run, we would expect our effect to be only temporary. We estimate the same regression as in Equation 12 but replace the change in investment by the change in log production employees. Figure 5 shows that the increase in production workers remains significant for four years in sectors that have been more exposed to the reduction in capital goods tariffs. After four years the difference between more and less exposed sectors is not statistically significant anymore. This result suggest that production workers and capital are complements for four years, but are independent of each other afterwards (Cobb-Douglas case).

\section{Conclusion}

In this paper we argue that trade liberalization has very nuanced consequences, some of which were overlooked by previous studies. We show that while output tariffs have no significant effect on invest- 
ment, a decline in the capital goods tariffs may substantially boost it. Firm-level data on employment paints an even more complex picture since a reduction in capital goods tariffs is associated with higher level of employment of production workers, while a reduction in input tariffs on non-capital goods has the opposite effect.

Our results have important policy implications. The effect of a reduction on tariff depends largely on which kind of tariffs are cut. While a reduction in capital goods tariffs can significantly stimulate investment, a reduction in tariffs on other inputs and output tariffs do not have effects on investment but can still help boosting productivity (Amiti and Konings, 2007; Topalova and Khandelwal, 2011).

In addition to heterogeneous responses to a reduction in different types of tariffs, there is substantial heterogeneity in responses across firms. Our results suggest that firms which refrain from importing due to fixed costs benefit most from the reduction in capital goods tariffs as the lower costs helps them to make importing profitable. 


\section{References}

Aghion, Philippe, Nick Bloom, Richard Blundell, Rachel Griffith, and Peter Howitt, "Competition and innovation: An inverted-U relationship," The Quarterly Journal of Economics, 2005, 120 (2), 701-728.

Amiti, Mary and Jozef Konings, “Trade liberalization, intermediate inputs, and productivity: Evidence from Indonesia," American Economic Review, 2007, 97 (5), 1611-1638.

Antras, Pol, Teresa C Fort, and Felix Tintelnot, "The margins of global sourcing: Theory and evidence from us firms," American Economic Review, 2017, 107 (9), 2514-64.

Atalay, Enghin, "How important are sectoral shocks?," American Economic Journal: Macroeconomics, 2017, 9 (4), 254-80.

Attanasio, Orazio, Pinelopi K Goldberg, and Nina Pavcnik, “Trade reforms and wage inequality in Colombia," Journal of development Economics, 2004, 74 (2), 331-366.

Autor, David, David Dorn, and Gordon H Hanson, "The China syndrome: Local labor market effects of import competition in the United States," American Economic Review, 2013, 103 (6), 2121-68.

Baqaee, David Rezza and Emmanuel Farhi, "Productivity and Misallocation in General Equilibrium.," Technical Report, National Bureau of Economic Research 2017.

Bernard, Andrew B, J Bradford Jensen, Stephen J Redding, and Peter K Schott, “Global firms," Journal of Economic Literature, 2018, 56 (2), 565-619.

Bøler, Esther Ann, Andreas Moxnes, and Karen Helene Ulltveit-Moe, "R\&D, international sourcing, and the joint impact on firm performance," American Economic Review, 2015, 105 (12), 3704-39.

Bustos, Paula, “Trade liberalization, exports, and technology upgrading: Evidence on the impact of MERCOSUR on Argentinian firms," American Economic Review, 2011, 101 (1), 304-40.

Chan, Mons, “How Substitutable are Labor and Intermediates?," Unpublished working paper. University of Minnesota, 2017.

Chirinko, Robert S, “ $\sigma$ : The long and short of it,” Journal of Macroeconomics, 2008, 30 (2), 671-686.

Eaton, Jonathan and Samuel Kortum, “Trade in capital goods,” European Economic Review, 2001, 45 (7), 1195-1235.

Estevadeordal, Antoni and Alan M Taylor, "Is the Washington Consensus dead? Growth, openness, and the great liberalization, 1970s-2000s," Review of Economics and Statistics, 2013, 95 (5), 1669-1690. 
Felbermayr, Gabriel J, Feodora Teti, and Erdal Yalcin, "On the profitability of trade deflection and the need for rules of origin," 2018.

Fernandes, Ana M., “Trade policy, trade volumes and plant-level productivity in Colombian manufacturing industries," Journal of International Economics, 2007, 71 (1), 52 - 71.

Goldberg, Pinelopi Koujianou, Amit Kumar Khandelwal, Nina Pavcnik, and Petia Topalova, "Imported intermediate inputs and domestic product growth: Evidence from India," The Quarterly Journal of Economics, 2010, 125 (4), 1727-1767.

Grossman, Gene M, Elhanan Helpman, Ezra Oberfield, and Thomas Sampson, "Balanced growth despite Uzawa," American Economic Review, 2017, 107 (4), 1293-1312.

Gutiérrez, Germán and Thomas Philippon, “Declining Competition and Investment in the US,” 2017.

Halpern, László, Miklós Koren, and Adam Szeidl, "Imported inputs and productivity," American Economic Review, 2015, 105 (12), 3660-3703.

Hsieh, Chang-Tai and Peter J Klenow, "Relative prices and relative prosperity," American Economic Review, 2007, 97 (3), 562-585.

Hummels, David, Rasmus Jørgensen, Jakob Munch, and Chong Xiang, “The wage effects of offshoring: Evidence from Danish matched worker-firm data," American Economic Review, 2014, 104 (6), 15971629.

Jones, Charles I, "Economic growth and the relative price of capital," Journal of Monetary Economics, 1994, 34 (3), 359-382.

Kalemli-Ozcan, Sebnem, Luc Laeven, and David Moreno, “Debt Overhang, Rollover Risk, and Corporate Investment: Evidence from the European Crisis,” Technical Report, National Bureau of Economic Research 2018.

Karabarbounis, Loukas and Brent Neiman, "The global decline of the labor share," The Quarterly journal of economics, 2013, 129 (1), 61-103.

Kugler, Maurice and Eric Verhoogen, "Prices, plant size, and product quality," The Review of Economic Studies, 2011, 79 (1), 307-339.

Lian, Weicheng, Natalija Novta, Evgenia Pugacheva, Yannick Timmer, and Petia B Topalova, "The Price of Capital Goods: A Driver of Investment Under Threat," IMF Working Paper, 2019. 
Long, J Bradford De and Lawrence H Summers, "Equipment investment and economic growth," The Quarterly Journal of Economics, 1991, 106 (2), 445-502.

_ and _ , "How strongly do developing economies benefit from equipment investment?," Journal of Monetary Economics, 1993, 32 (3), 395-415.

Melitz, Marc J, “The impact of trade on intra-industry reallocations and aggregate industry productivity,” Econometrica, 2003, 71 (6), 1695-1725.

Muendler, Marc-Andreas, "Trade, technology and productivity: a study of brazilian manufacturers 19861998," 2004.

Oberfield, Ezra and Devesh Raval, "Micro data and macro technology," Technical Report, National Bureau of Economic Research 2014.

Pavcnik, Nina, "Trade liberalization, exit, and productivity improvements: Evidence from Chilean plants," The Review of Economic Studies, 2002, 69 (1), 245-276.

Peter, Alessandra and Cian Ruane, “The Aggregate Importance of Intermediate Input Substitutability,” Job market paper, 2017.

Pierce, Justin R and Peter K Schott, "Investment responses to trade liberalization: Evidence from US industries and establishments," Journal of International Economics, 2018, 115, 203-222.

Raval, Devesh R, “The micro elasticity of substitution and non-neutral technology," The RAND Journal of Economics, 2014.

Restuccia, Diego and Carlos Urrutia, "Relative prices and investment rates," Journal of Monetary Economics, 2001, 47 (1), 93-121.

Topalova, Petia and Amit Khandelwal, “Trade liberalization and firm productivity: The case of India," Review of Economics and Statistics, 2011, 93 (3), 995-1009.

Torres, Mauricio and Germán Romero, "Efectos de la reforma estructural arancelaria en la protección efectiva arancelaria de la economía colombiana," Cuadernos de Economía, 2013, 32 (59), 265-303. 


\section{Tables}

Table 1: Descriptive Statistics

\begin{tabular}{lccccc}
\hline \hline & mean & p50 & p25 & p75 & sd \\
\hline$\Delta$ Investment & -0.00230 & 0 & -0.0210 & 0.0172 & 0.122 \\
investment_2010 & 0.0571 & 0.0116 & 0 & 0.0629 & 0.109 \\
investment_2011 & 0.0548 & 0.0121 & 0 & 0.0619 & 0.103 \\
employees & 75.46 & 25 & 12 & 70 & 148.9 \\
ln_sales & 14.78 & 14.46 & 13.48 & 15.80 & 1.745 \\
In_fixed_assets & 13.68 & 13.41 & 12.27 & 14.89 & 2.096 \\
importer_2010 & 0.221 & 0 & 0 & 0 & 0.415 \\
importer_2011 & 0.206 & 0 & 0 & 0 & 0.405 \\
import_entry & 0.0393 & 0 & 0 & 0 & 0.194 \\
\hline Observations & 8498 & & & & \\
\hline \hline
\end{tabular}

Note: the table reports descriptive statistics of the selected variables from the 2011 Colombian Annual Manufacturers Survey. The description of the data can be found in subsection 2.1 
Table 2: Descriptive Statistics - Reduction in Tariffs

\begin{tabular}{lccccccc} 
& mean & p10 & p25 & p50 & p75 & p90 & sd \\
\hline$\Delta T_{2011}^{I}$ & -0.942 & -2.007 & -1.449 & -0.783 & -0.300 & -0.0170 & 0.849 \\
$\Delta T_{2011}^{I, C}$ & -0.296 & -0.820 & -0.143 & -0.0336 & -0.00439 & -0.000347 & 0.727 \\
$\Delta T_{2011}^{I, \neg C}$ & -0.830 & -1.834 & -1.274 & -0.589 & -0.250 & -0.0110 & 0.857 \\
$\Delta T_{2011}^{O}$ & -4.416 & -7.364 & -6.391 & -3.735 & -2.781 & -1.900 & 2.094 \\
\hline Observations & 132 & & & & & & \\
\hline \hline
\end{tabular}

Note: the table reports descriptive statistics the changes in input and output tariffs constructed in subsection 2.2

Table 3: Descriptive Statistics - Reduction in Tariffs, Alternative Measure

\begin{tabular}{lccccccc}
\hline \hline & mean & $\mathrm{p} 10$ & $\mathrm{p} 25$ & $\mathrm{p} 50$ & $\mathrm{p} 75$ & $\mathrm{p} 90$ & $\mathrm{sd}$ \\
\hline$\Delta \widetilde{T}_{2011}^{I}$ & -4.511 & -7.597 & -5.030 & -4.463 & -3.563 & -2.516 & 1.668 \\
$\Delta \widetilde{T}_{2011}^{I, C}$ & -0.436 & -0.861 & -0.531 & -0.249 & -0.140 & -0.0319 & 0.497 \\
$\Delta \widetilde{T}_{2011}^{I, \neg C}$ & -4.106 & -7.565 & -4.658 & -3.444 & -2.999 & -2.262 & 1.818 \\
\hline Observations & 110 & & & & & & \\
\hline \hline
\end{tabular}

Note: the table reports descriptive statistics the changes in input and output tariffs constructed in subsection 2.3 
Table 4: Baseline

\begin{tabular}{lcccc}
\hline \hline & $(1)$ & $(2)$ & $(3)$ & $(4)$ \\
Dependent variable: & & \multicolumn{2}{c}{$\Delta$ Investment } \\
\hline$\Delta$ Input Tariffs & -0.116 & & & \\
& $(0.119)$ & & & \\
& & & & \\
$\Delta$ Capital Input Tariffs & & $-0.377^{* * *}$ & $-0.371^{* * *}$ & $-0.370^{* * *}$ \\
& & $(0.055)$ & $(0.052)$ & $(0.051)$ \\
$\Delta$ Other Input Tariffs & & & -0.0478 & -0.0547 \\
& & & $(0.036)$ & $(0.055)$ \\
$\Delta$ Output Tariffs & & & & 0.00553 \\
& & & & $(0.040)$ \\
\hline Observations & & & & 9110 \\
Controls & 9110 & 9110 & 910 & Yes \\
\hline \hline
\end{tabular}

Note: the table represents the estimated coefficients of the regression of changes in investment rate of Colombian manufacturing firms in 2011 on the measure of the exposure to tariff reduction, constructed in subsection 2.2. Column (1) reports the results for the overall change in tariffs; column (2) reports the results when exposure is calculated based on changes in capital goods tariffs only; column (3) shows the results for the tariffs on capital and other goods; while column (4) also controls for the changes in output tariffs. All regressions include lagged values of log fixed assets and sales as controls. Standard errors are clustered at the sector level and reported in parentheses. ${ }^{*},{ }^{* *}$, and ${ }^{* * *}$ represent the $5 \%, 1 \%$, and $0.1 \%$ significance levels respectively. 
Table 5: Instrumental Variable Regression

\begin{tabular}{|c|c|c|c|}
\hline & (1) & (2) & (3) \\
\hline & OLS & OLS & IV \\
\hline Dependent variable: & \multicolumn{3}{|c|}{$\Delta$ Investment } \\
\hline \multirow[t]{2}{*}{ Capital Input Tariffs 2010} & $0.193^{* * *}$ & & \\
\hline & $(0.055)$ & & \\
\hline \multirow[t]{2}{*}{$\Delta$ Capital Input Tariffs } & & $-0.386^{* * *}$ & $-0.373^{* * *}$ \\
\hline & & $(0.056)$ & $(0.079)$ \\
\hline Observations & 9110 & 9110 & 9110 \\
\hline
\end{tabular}

Note: the table represents the estimated coefficients of the regression of changes in investment rate of Colombian manufacturing firms in 2011 on different measures of the exposure to tariff reduction. Column (1) reports the results for the level of capital goods tariffs in 2010; column (2) reports the results when exposure is the change in capital goods tariffs between 2011 and 2010; column (3) shows the results for an IV regression, where the change in capital goods tariffs between 2011 and 2010 is instrumented with its level in 2010. Standard errors are clustered at the sector level and reported in parentheses. ${ }^{*},{ }^{* *}$, and ${ }^{* * *}$ represent the $5 \%, 1 \%$, and $0.1 \%$ significance levels respectively. 
Table 6: Interaction with Size Quartiles

\begin{tabular}{lcc|cc}
\hline \hline & $(1)$ & $(2)$ & $(3)$ & $(4)$ \\
\multicolumn{1}{c}{$\begin{array}{c}\text { Dependent variable: } \\
\text { Interaction: }\end{array}$} & \multicolumn{3}{c}{$\Delta$ Investment } \\
& \multicolumn{2}{c}{ Employees } & \multicolumn{2}{c}{ Sales } \\
\hline Capital Input Tariffs & -0.0155 & $-0.367^{* * *}$ \\
& $(0.141)$ & & $(0.123)$ \\
2nd quartile $\times \Delta$ Capital Input Tariffs & -0.384 & -0.385 & 0.342 & 0.342 \\
& $(0.261)$ & $(0.261)$ & $(0.408)$ & $(0.406)$ \\
3rd quartile $\times \Delta$ Capital Input Tariffs & $-0.648^{* *}$ & $-0.647^{* *}$ & $-0.421^{* *}$ & $-0.423^{* *}$ \\
& $(0.285)$ & $(0.287)$ & $(0.170)$ & $(0.171)$ \\
4th quartile $\times \Delta$ Capital Input Tariffs & $-0.429^{* *}$ & $-0.428^{* *}$ & -0.0617 & -0.0625 \\
& $(0.160)$ & $(0.162)$ & $(0.122)$ & $(0.120)$ \\
\hline Observations & 9110 & 9110 & 9110 & 9110 \\
Controls & Yes & Yes & Yes & Yes \\
Sector FE & No & Yes & No & Yes \\
\hline \hline
\end{tabular}

Note: the table represents the estimated coefficients of the regression of changes in investment rate of Colombian manufacturing firms in 2011 on the measure of the exposure to tariff reduction, constructed in subsection 2.2 and interacted with the indicators for quartiles of total employment and sales. The quartiles were calculated across firms within broad ISIC sectors. Columns (2) and (4) report the results when sectoral fixed effects are included as controls. All regressions include lagged values of log fixed assets and sales. Standard errors are clustered at the sector level and reported in parentheses. ${ }^{*},{ }^{* *}$, and ${ }^{* * *}$ represent the $5 \%, 1 \%$, and $0.1 \%$ significance levels respectively. 
Table 7: Import Entry - Probit Regression

\begin{tabular}{|c|c|c|c|c|}
\hline & (1) & (2) & (3) & (4) \\
\hline Dependent variable: & \multicolumn{4}{|c|}{ Import Entry } \\
\hline \multirow[t]{2}{*}{$\Delta$ Input Tariffs } & -0.0206 & & & \\
\hline & $(0.032)$ & & & \\
\hline \multirow[t]{2}{*}{$\Delta$ Capital Input Tariffs } & & $-0.0560^{*}$ & $-0.0546^{* *}$ & $-0.0597^{*}$ \\
\hline & & $(0.029)$ & $(0.026)$ & $(0.032)$ \\
\hline \multirow[t]{2}{*}{$\Delta$ Other Input Tariffs } & & & -0.00964 & 0.0329 \\
\hline & & & $(0.028)$ & $(0.028)$ \\
\hline \multirow[t]{2}{*}{$\Delta$ Output Tariffs } & & & & $-0.0361^{* *}$ \\
\hline & & & & $(0.018)$ \\
\hline Observations & 9110 & 9110 & 9110 & 9110 \\
\hline Controls & Yes & Yes & Yes & Yes \\
\hline
\end{tabular}

Note: the table represents the estimated coefficients from a probit regression of a dummy that equals to one if a firm changes a status from non-importer in 2010 to importer in 2011. Column (1) reports the results for the overall change in tariffs; column (2) reports the results when exposure is calculated based on changes in capital goods tariffs only; column (3) shows the results for the tariffs on capital and other goods; while column (4) also controls for the changes in output tariffs. All regressions include lagged values of log fixed investment and sales as controls. Standard errors are clustered at the sector level and reported in parentheses. ${ }^{*},{ }^{* *}$, and *** represent the $5 \%, 1 \%$, and $0.1 \%$ significance levels respectively. 
Table 8: Baseline with Additional Controls

\begin{tabular}{|c|c|c|c|c|}
\hline & (1) & (2) & (3) & $(4)$ \\
\hline Dependent variable: & \multicolumn{4}{|c|}{$\Delta$ Investment } \\
\hline \multirow[t]{2}{*}{$\Delta$ Capital Input Tariffs } & $-0.375^{* * *}$ & $-0.372^{* * *}$ & $-0.373^{* * *}$ & $-0.376^{* * *}$ \\
\hline & $(0.049)$ & $(0.050)$ & $(0.051)$ & $(0.050)$ \\
\hline \multirow[t]{2}{*}{$\Delta$ Other Input Tariffs } & $-0.0918^{* *}$ & -0.0544 & -0.0493 & -0.0755 \\
\hline & $(0.042)$ & $(0.053)$ & $(0.055)$ & $(0.056)$ \\
\hline \multirow[t]{2}{*}{$\Delta$ Output Tariffs } & 0.00478 & 0.00516 & 0.00807 & 0.0144 \\
\hline & $(0.037)$ & $(0.038)$ & $(0.041)$ & $(0.040)$ \\
\hline \multirow[t]{2}{*}{ lagged $\ln ($ Fixed Assets) } & & -0.0806 & -0.138 & -0.0364 \\
\hline & & $(0.061)$ & $(0.152)$ & $(0.146)$ \\
\hline \multirow[t]{2}{*}{ lagged $\ln ($ Sales $)$} & & & 0.0806 & 0.00820 \\
\hline & & & $(0.153)$ & $(0.149)$ \\
\hline \multirow[t]{2}{*}{ lagged $\ln (T F P)$} & & & -0.157 & -0.143 \\
\hline & & & $(0.146)$ & $(0.146)$ \\
\hline \multirow[t]{2}{*}{$\Delta \ln ($ Fixed Assets $)$} & & & & $0.907^{* * *}$ \\
\hline & & & & $(0.225)$ \\
\hline \multirow[t]{2}{*}{$\Delta \ln ($ Sales $)$} & & & & -0.0465 \\
\hline & & & & $(0.209)$ \\
\hline Observations & 9105 & 9105 & 9105 & 9105 \\
\hline
\end{tabular}

Note: the table represents the estimated coefficients of the regression of changes in investment rate of Colombian manufacturing firms in 2011 on the measure of the exposure to tariff reduction, constructed in subsection 2.2 Column (1) reports the results for the overall change in tariffs; column (2) reports the results when exposure is calculated based on changes in capital goods tariffs only; column (3) shows the results for the tariffs on capital and other goods; while column (4) also controls for the changes in output tariffs. All regressions include lagged values of log fixed assets and sales as controls, as in Table 4, but also lagged logs of revenue TFP, change in log fixed assets, change in log sales, as in Kalemli-Ozcan et al. (2018). Standard errors are clustered at the sector level and reported in parentheses. ${ }^{*},{ }^{* *}$, and ${ }^{* * *}$ represent the $5 \%$, $1 \%$, and $0.1 \%$ significance levels respectively. 
Table 9: The effect of tariffs on employment

\begin{tabular}{|c|c|c|c|c|}
\hline & (1) & $(2)$ & (3) & $(4)$ \\
\hline Dependent variable: & \multicolumn{4}{|c|}{$\Delta$ Employment } \\
\hline \multirow[t]{2}{*}{$\Delta$ Tariffs } & $1.258^{* * *}$ & & & \\
\hline & $(0.426)$ & & & \\
\hline \multirow[t]{2}{*}{$\Delta$ Capital Input Tariffs } & & -0.666 & $-0.847^{* * *}$ & $-0.877^{* * *}$ \\
\hline & & $(0.401)$ & $(0.218)$ & $(0.243)$ \\
\hline \multirow[t]{2}{*}{$\Delta$ Other Input Tariffs } & & & $1.428^{* * *}$ & $1.718^{* * *}$ \\
\hline & & & $(0.359)$ & $(0.424)$ \\
\hline \multirow[t]{2}{*}{$\Delta$ Output Tariffs } & & & & -0.233 \\
\hline & & & & $(0.164)$ \\
\hline Observations & 8954 & 8954 & 8954 & 8954 \\
\hline Controls & Yes & Yes & Yes & Yes \\
\hline
\end{tabular}

Note: the table represents the estimated coefficients of the regression of changes in log of employment of Colombian manufacturing firms in 2011 on the measure of the exposure to tariff reduction, constructed in subsection 2.2 Column (1) reports the results for the overall change in tariffs; column (2) reports the results when exposure is calculated based on changes in capital goods tariffs only; column (3) shows the results for the tariffs on capital and other goods; while column (4) also controls for the changes in output tariffs. All regressions include lagged values of $\log$ fixed assets and sales as controls, as in Table 4, but also lagged logs of revenue TFP, change in log fixed assets, change in log sales, as in Kalemli-Ozcan et al. (2018). Standard errors are clustered at the sector level and reported in parentheses. ${ }^{*},{ }^{* *}$, and ${ }^{* * *}$ represent the $5 \%$, $1 \%$, and $0.1 \%$ significance levels respectively. 


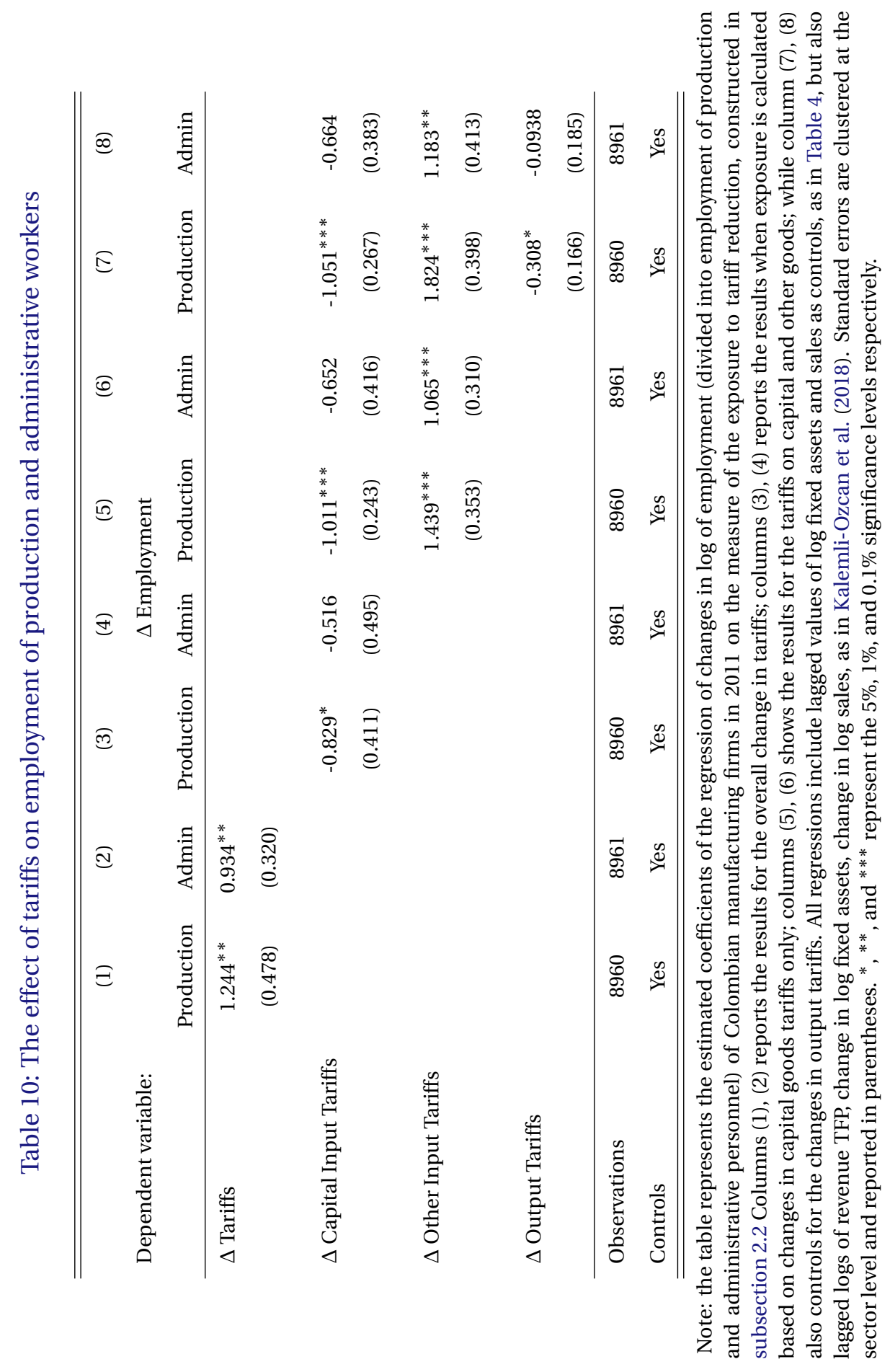


Table 11: Baseline Regression using Alternative Tariff Measures

\begin{tabular}{|c|c|c|c|c|}
\hline & (1) & $(2)$ & (3) & (4) \\
\hline Dependent variable: & \multicolumn{4}{|c|}{$\Delta$ Investment } \\
\hline \multirow[t]{2}{*}{$\Delta$ Input Tariffs } & 0.0515 & & & \\
\hline & $(0.038)$ & & & \\
\hline \multirow[t]{2}{*}{$\Delta$ Capital Input Tariff } & & $-0.587^{* * *}$ & $-0.536^{* * *}$ & $-0.572^{* * *}$ \\
\hline & & $(0.169)$ & $(0.171)$ & $(0.179)$ \\
\hline \multirow[t]{2}{*}{$\Delta$ Other Input Tariffs } & & & 0.0421 & 0.0789 \\
\hline & & & $(0.045)$ & $(0.060)$ \\
\hline \multirow[t]{2}{*}{$\Delta$ Output Tariffs } & & & & -0.0840 \\
\hline & & & & $(0.065)$ \\
\hline Observations & 8849 & 8849 & 8849 & 8849 \\
\hline Controls & Yes & Yes & Yes & Yes \\
\hline
\end{tabular}

Note: the table represents the estimated coefficients of the regression of changes in investment rate of Colombian manufacturing firms in 2011 on the measure of the exposure to tariff reduction, constructed in subsection 2.3 (input tariffs) and subsection 2.2 (output tariff). Column (1) reports the results for the overall change in tariffs; column (2) reports the results when exposure is calculated based on changes in capital goods tariffs only; column (3) shows the results for the tariffs on capital and other goods; while column (4) also controls for the changes in output tariffs. All regressions include lagged values of log fixed assets and sales as controls. Standard errors are clustered at the sector level and reported in parentheses. ${ }^{*},{ }^{* *}$, and ${ }^{* * *}$ represent the $5 \%, 1 \%$, and $0.1 \%$ significance levels respectively. 


\section{Figures}

Figure 1: Distribution of MFN Tariffs changes in Colombia in 2011

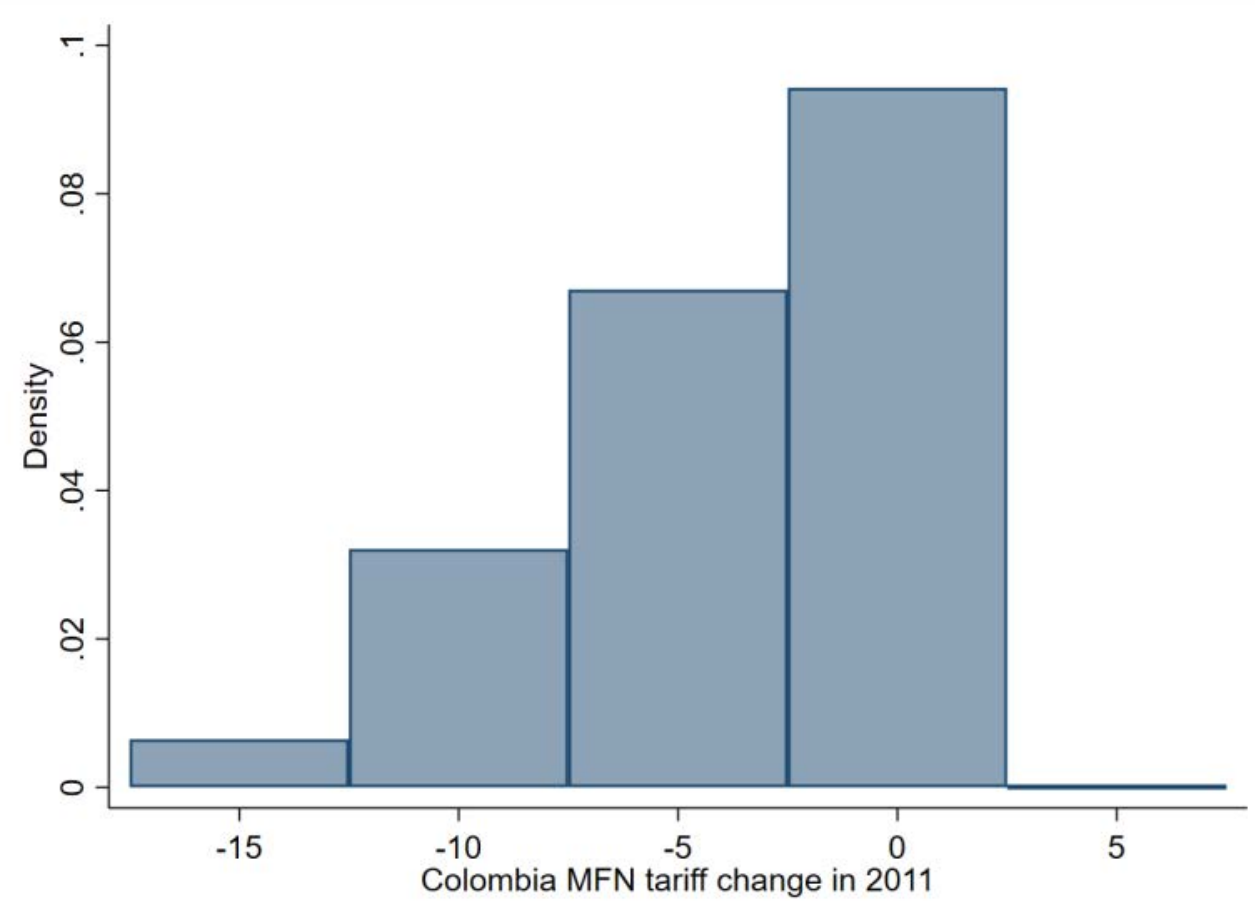

Note: this figure plots the density of changes in Colombian MFN tariff rates. Source: Felbermayr et al. (2018). 
Figure 2: Distribution of MFN Tariffs changes in Colombia in 2011

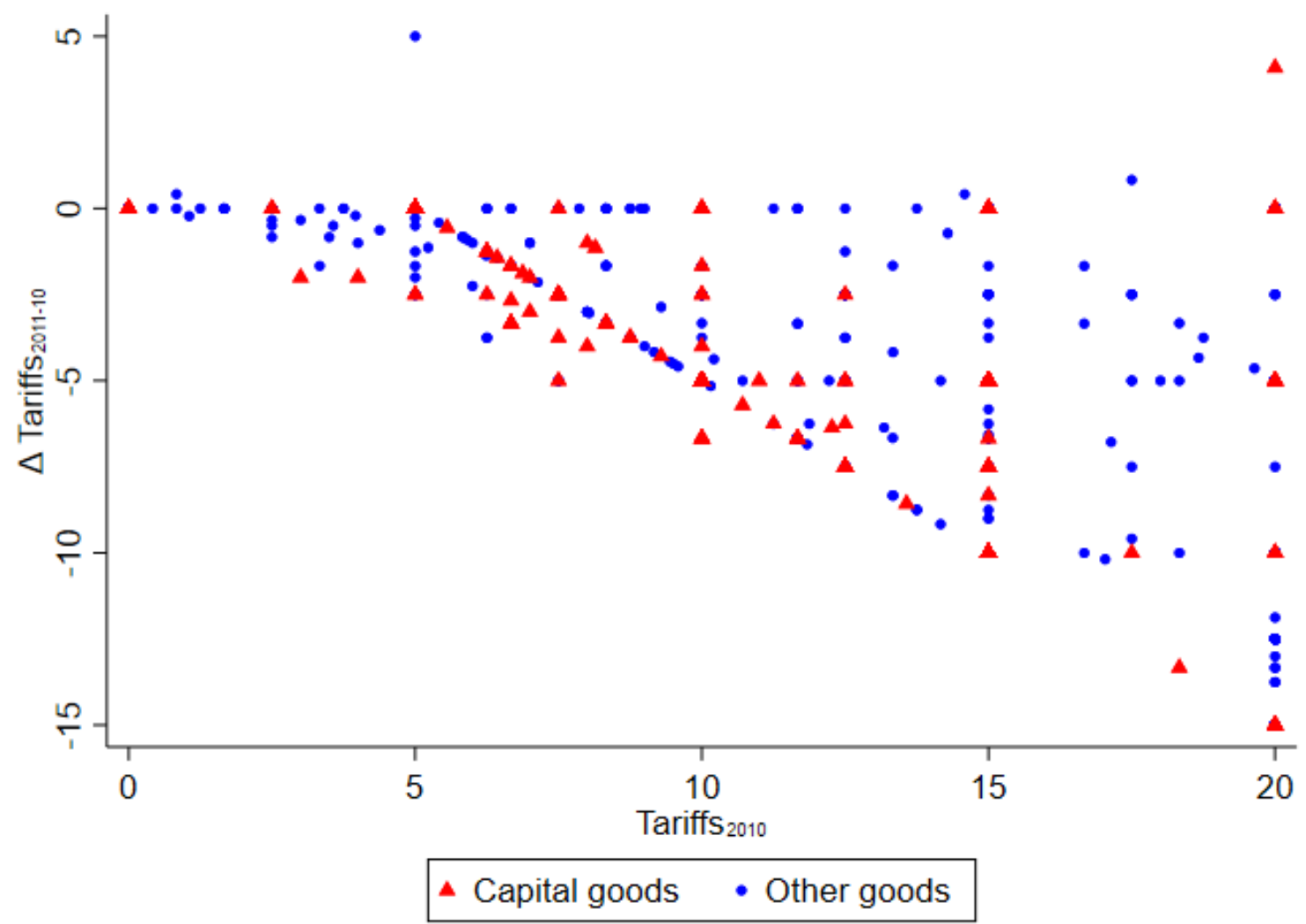

Note: this figure plots the density of changes in Colombian MFN tariff rates between 2011 and 2010 against the level of tariffs in 2010. Source: Felbermayr et al. (2018). 
Figure 3: Evolution of Input Tariffs Over Time

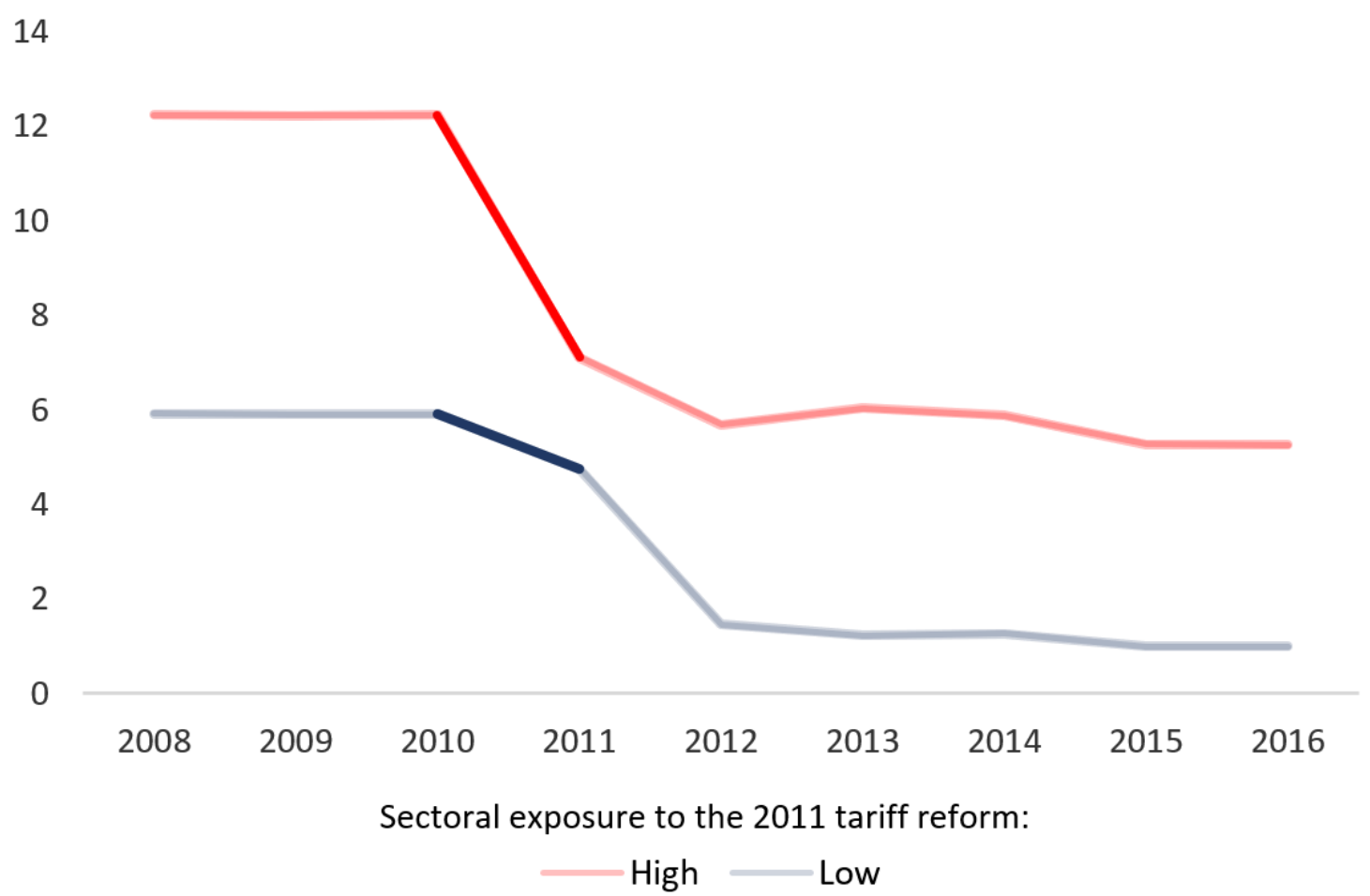

Note: this figure plots the evolution of input tariffs defined in subsection 2.2 over time for two sectors. The high-exposure sector experienced the biggest reduction in input tariffs in 2011 while the low-exposure sector experienced the lowest decline. Source: Felbermayr et al. (2018). 
Figure 4: Dynamic Response of Investments to Capital Goods Input Tariffs cut

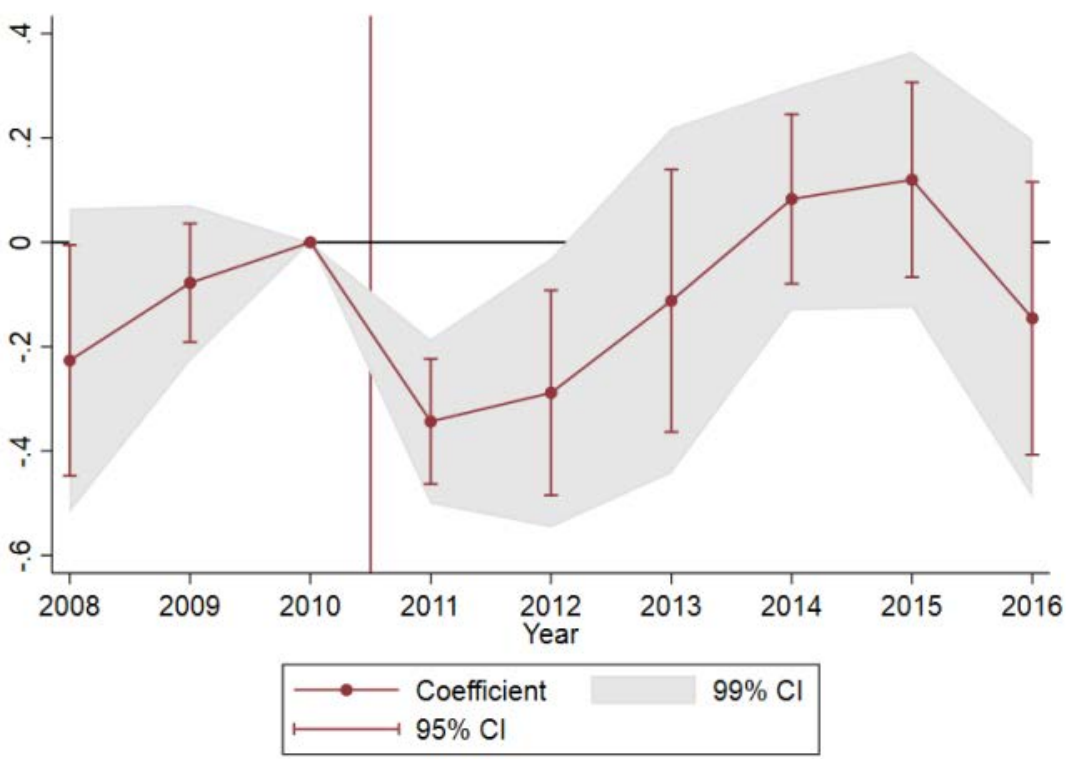

Note: this figure plots the estimated coefficients of a regression equation Equation 12. The left-hand side variable is the difference between investment rates in year $t$ plotted on horizontal axis and investment rate in 2010. The variable of interest on the right-hand side is the measure of reduction in capital goods input tariffs in 2011, defined in subsection 2.2 
Figure 5: Dynamic Response of Production Workers to Capital Goods Input Tariffs cut

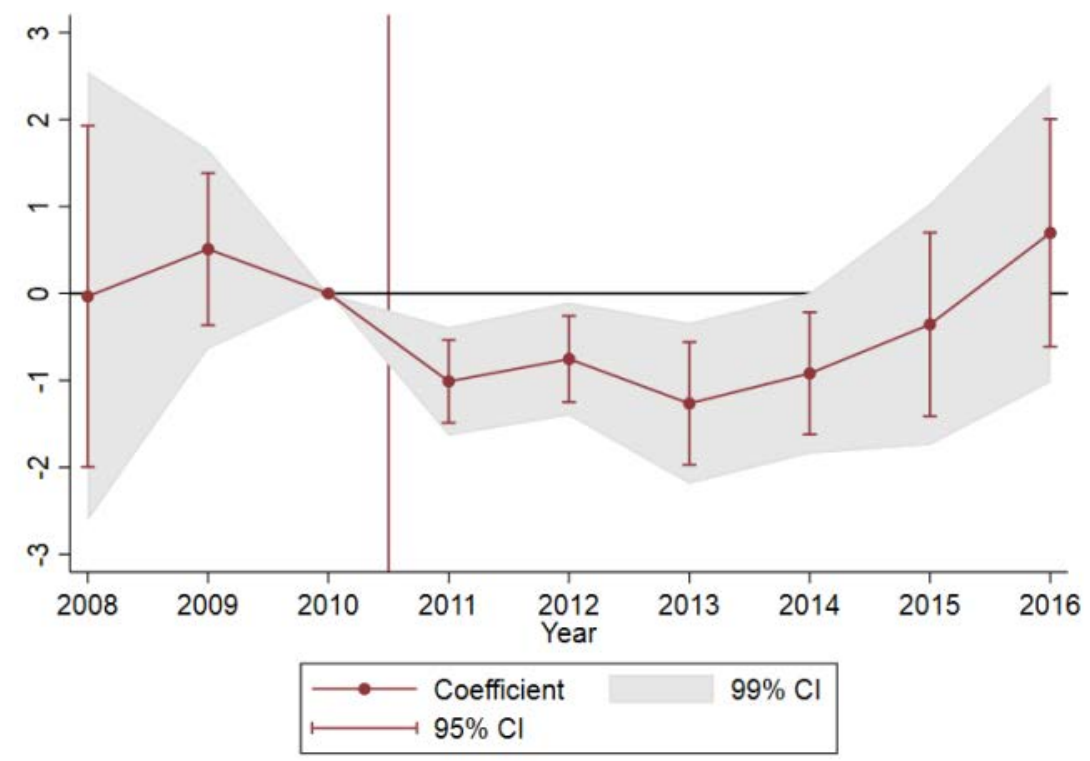

Note: this figure plots the estimated coefficients of a regression equation Equation 12. The left-hand side variable is the difference between log number of production workers in year $t$ plotted on horizontal axis and log number of production workers in 2010. The variable of interest on the right-hand side is the measure of reduction in capital goods input tariffs in 2011, defined in subsection 2.2 